PRINT ISSN 1119-8362

Electronic ISSN 1119-8362
Full-text Available Online at https://www.ajol.info/index.php/jasem http://ww.bioline.org.br/ja
J. Appl. Sci. Environ. Manage.

Vol. 24 (6) 979-983 June 2020

\title{
Livelihoods and Biodiversity Conservation: A Survey of Socioeconomic Activities around Pandam Game Reserve, Plateau State - Nigeria
}

\author{
*1,2DA'AN, SA; ${ }^{3}$ JIDANGKAT, M; ${ }^{1,4}$ CHASKDA, AA; ${ }^{1}$ MWANSAT, GS \\ ${ }^{*}$ Zoology Department University of Jos, P.M.B 2084, Jos-Nigeria \\ ${ }^{2}$ Department of Natural Sciences, Oswald Waller College of Education Lifidi, P. O. Box 39, Shendam, Plateau State, Nigeria. \\ ${ }^{3}$ College of Art, Science and Technology, P.M.B 003, Shendam, Plateau State \\ ${ }^{4}$ A.P.Leventis Ornithological Research Institute, Zoology Department University of Jos P.M.B 2084, Jos-Nigeria \\ *Corresponding Author Email: ansamdaan@gmail.com
}

\begin{abstract}
This research surveyed some socio-economic activities of communities around Pandam Game Reserve (PGR) central Nigeria to determine their implications for biodiversity Conservation in PGR. Data were collected using structured questionnaires and field observations. Results showed a $100 \%$ response to questionnaires administered. Eighty three percent $(83 \%)$ of the respondents were males while $17 \%$ were females. Eighty percent $(80 \%)$ attended at least primary school level of education while $20 \%$ had no form of formal education. Prominent among occupation of respondents was farming with $40 \%$ and the occupation of respondents with list response was hunting with $1 \%$. Field observations showed the presence of the following human activities: logging, firewood collection, fishing, farm encroachment, cattle grazing and poaching. The implication of these socio-economic activities in PGR if left uncontrolled could result to biodiversity lost. A multi-stakeholder approach and participatory management of the reserve which wil consider the socio-economic concerns of locals have been suggested as a critical component for building cooperation. These if properly exploited is believed will contribute substantially to biodiversity sustainability in PGR.
\end{abstract}

DOI: $\underline{\text { https://dx.doi.org/10.4314/jasem.v24i6.6 }}$

Copyright: Copyright (C) 2020 DA'AN et al. This is an open access article distributed under the Creative Commons Attribution License (CCL), which permits unrestricted use, distribution, and reproduction in any medium, provided the original work is properly cited.

Dates: Received: 13 October 2019; Revised: 17 May 2020; Accepted: 09 June 2020

Keywords: Communities, Biodiversity, Conservation, Pandam Game Reserve.

Biodiversity rich areas are increasingly being surrounded by growing human populations with attendant pressures (Joppa, 2012) especially in developing countries (Mwanfupe, 1998). Excessive anthropogenic activities such as poaching, livestock herding, fuel wood collection, farm encroachment, logging and bush burning causes distortion in the equilibrium of ecosystems (Connell and Slatyer 1977, Pickett et al., 1992, Mathisen et al., 2012). For example, livestock grazing has been identified as a major driver of ecosystem change and has been associated with significant declines in various bird species in Britain and worldwide (Vickery et al., 2001; Evans et al., 2006). While any illegal human activities conducted in any protected area are punishable by the appropriately laws, irretrievable damages are often impacted on wildlife by such activities (Shanthikumar and Atilola, 1990). For example, buffalo populations were reported to have crashed at the Yankari Game Reserve-Nigeria in 1981 as a result of infection from cattle grazing in the Reserve (Mohammed et al., 2010). The overall effect of high density anthropogenic activities is biodiversity loss (International Council for Protection of Birds, 1992, Evans et al., 2006; EmmaOkafo et al., 2009; Abdu-Raheem and Worth, 2013).
Although it has been opined that rural communities dwelling around biodiversity areas utilise wildlife resources more sustainably than the urban dwellers (Fernández-Baca and Martin, 2007; Githiru, 2007), it is unsustainable to use such resources as basic source of livelihood support by these growing populations around biodiversity areas. This is because livelihood support activities have been known to be key drivers of human activities in protected areas (Robert and Brian, 2006). It is increasingly becoming very clear that for conservation to succeed through the protected area system in the future, there must be collaborations at different levels with indigenous people around protected areas (Fernández-Baca and Martin, 2007; Kothari, 2008; Anne et al., 2010). Therefore, participatory protected area management will better succeed when socioeconomic needs of local communities are understood and attended to (DeGeorges and Reilly, 2009; Chami, 2016). Several anthropogenic activities have been reported in Pandam Game Reserve (PGR), (Ezealor, 2002; Dami and Manu, 2008). However, very little is known about the relationship(s) between these activities and their potential drivers such as socio-economic activities of surrounding communities. This research therefore,

*Corresponding Author Email: ansamdaan@gmail.com 
investigated some socio-economic activities of people living in surrounding communities of PGR in relation to observed human activities in parts of PGR near these communities.

\section{MATERIALS AND METHODS}

Study site: The research was conducted in Pandam Game Reserve (0848’N 0909'E; Plate 1), Quan-pan Local Government Area of Plateau State, Nigeria. It is located beside Lafia-Shendam road to the north of the Benue River. The reserve is bounded on the east by Namu and Kayarda towns and on the north and west by Dep River and on the south by Aningo and Pandam towns. It has Guinea Savanna vegetation and occupies an area of 22,400 ha. The wet season lasts from April to October and annual rainfall is $1000-1500 \mathrm{~mm}$. The land slopes gradually southwards and forms a basin, the Pandam Lake, which is a wetland complex of approximately $2 \mathrm{~km}^{2}$ (Ezealor, 2002; Akosim et al., 2007).

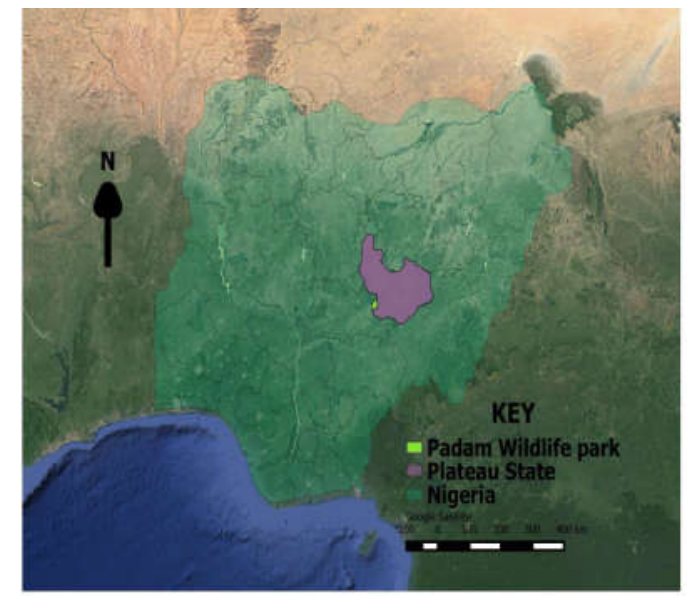

Plate 1: Google Satellite image Map of Nigeria showing Pandam Wildlife Park/Reserve (Google, 2016)

Poaching, Livestock grazing, bush burning, timber and fire wood collection activities have been reported in the Park in the past (Ezealor, 2002; Dami and Manu, 2008). All data were collected between November 2015 and October 2016.

Data collection: Data on socio-economic activities of people living in surrounding communities ware collected using structured questionnaires. Five communities around PGR were visited and structured questionnaires administered; interviews were conducted where individuals could not read or write. Twenty questionnaires were administered in each of the communities. The communities involved in the survey were: Pandam, Gunkaroghom, Monday, Kayarda and Gallo. The questionnaires were used to assess sexes, educational status, occupation, and sources of animal protein (source of meat) of the respondents. Field observations of human activities were made along $2 \mathrm{Km}$ transects (Cf. Bibby et al., 2000) in parts of PGR near each of the communities where questionnaires were administered. Human activities were then noted relative to the position of the nearest of the five surrounding communities.

Data analysis: Descriptive statistics was used for data analyses using the Statistical Package for Social Sciences (SPSS), (IBM SPSS version 20, 2011; Microsoft excel, 2006).

\section{RESULTS AND DISCUSSION}

One hundred percent (100\%) response was obtained from the questionnaires administered. Eighty three percent $(83 \%)$ of respondents were males while seventeen percent $(17 \%)$ were females.

Educational status of respondents: Gunkaroghom community had the highest number of educated respondents while Gallo had the highest number of uneducated respondents (Figure 1).

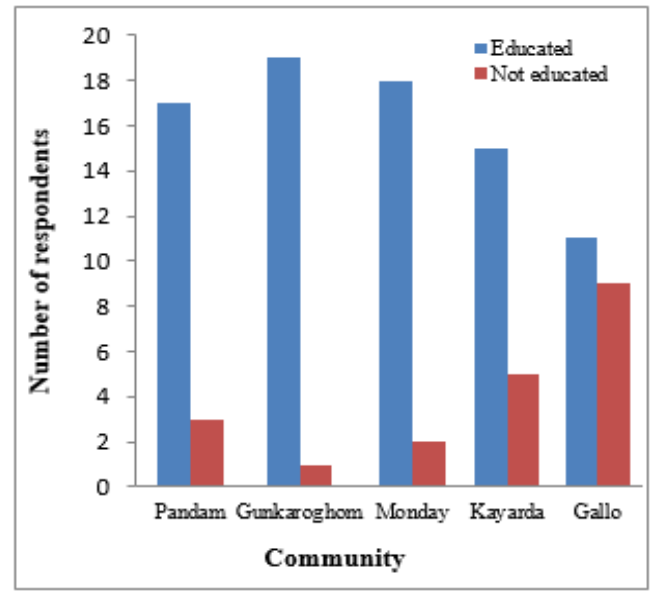

Fig 1: Educational status in each community

Gunkaroghom had the highest number of educated people with fewer observed human activities in parts of PGR close to it while Gallo which had the highest number of uneducated people followed by Kayarda were observed to have more human activities. It is known that education is a critical element in the success of biodiversity conservation (DeSherbinin and Freudenberger, 1998). It is therefore expected that a more educated local population surrounding protected areas will be more exposed to the importance of conserving natural resources, hence more sustainably in exploiting resources (Githiru, 2007; Robert and Brian, 2006). Through education, indigenous and traditional knowledge that is useful for conservation are enhanced (Mbugua, 2012). Levels of education and human activities near PGR as seen in Gunkaroghom 
and Gallo may be a clear indication of this fact. Occupation of respondents: Forty percent (40\%) of the total study population had farming as their occupation with both Gunkaroghom and Gallo communities making equal contributions of $12 \%$ each (Table 1 ). Despite levels of education, $40 \%$ of respondents were farmers. It is worthy of note that Gunkaroghom community which had the highest number of educated respondents contributed equal percentage of farmers to the total just as Gallo community which had the highest number of uneducated respondents. This suggests the need for more farmlands, the ripple effect of lack of these farmlands may be encroachment into PGR as observed in the field and as have been reported in the past (Ezealor, 2002; Dami and Manu, 2008).

\begin{tabular}{llllllllll}
\multicolumn{8}{c}{ Table 1. Occupation of respondents in each of the communities } \\
\hline Community & Hunter & $\begin{array}{l}\text { Civil } \\
\text { servant }\end{array}$ & $\begin{array}{l}\text { House } \\
\text { wife }\end{array}$ & Business & Applicant & Farmer & Student & $\begin{array}{c}\text { Cattle } \\
\text { herder }\end{array}$ & Fishing \\
\hline Pandam & 2 & 3 & 1 & 5 & 1 & 5 & 2 & 0 & 1 \\
Gunkaroghom & 0 & 5 & 0 & 0 & 0 & $\mathbf{1 2}$ & 3 & 0 & 0 \\
Monday & 1 & 4 & 1 & 4 & 1 & 5 & 4 & 0 & 0 \\
Kayarda & 2 & 2 & 0 & 1 & 0 & 6 & 9 & 0 & 0 \\
Gallo & 0 & 1 & 0 & 4 & 0 & $\mathbf{1 2}$ & 1 & 2 & 0 \\
\hline \% Total & 5 & 15 & 2 & 14 & 2 & $\mathbf{4 0}$ & 19 & 2 & 1 \\
\hline
\end{tabular}

Sources of animal protein (source of meat) of the respondents: Forty two percent $(42 \%)$ of the study population sourced their meat protein from bush meat. However, $58 \%$ of the population got their meat protein from other sources (Figure 2) including fish. Monday community had the highest percentage dependence on bush meat while Gunkaroghom had the least (Figure 3 ). The need for meat protein source may also be a driver of poaching activities like hunting; this is more so that $42 \%$ of the study population depended on 'bush meat'.

It is known that locals nowadays engage in poaching more for commercial purposes rather than for subsistence; this may be due to the availability of more sophisticated hunting implements like guns (Chami, 2016). Socio-economic activities have been known to be key drivers of human activities in protected areas (Robert and Brian, 2006).

Other human activities such as firewood collection, logging and cattle herding observed in PGR degrades environments and ecosystems in catastrophic measures (Connell and Slatyer 1977, Pickett et al., 1992; Carlos et al., 1998, Mwansat et al., 2016). For example, cattle herding has been identified as a major driver of ecosystem change and has been associated with significant declines in various bird species in Britain and worldwide (Vickery et al, 2001; Evans et al, 2006).

Field observations revealed the presence of the following human activities: firewood collection, farm encroachment, cattle herding, logging and hunting. Generally, there were more cattle grazing activities in dry than wet season. Relative to the position of surrounding communities, there were fewer cattle grazing and hunting activities near Gunkaroghom but more around Kayarda and Gallo.

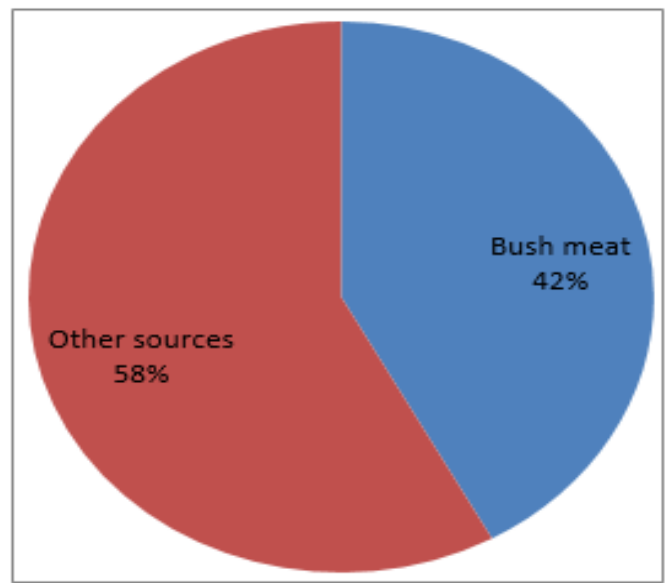

Fig 2: Proportion of bush meat protein source in the study population

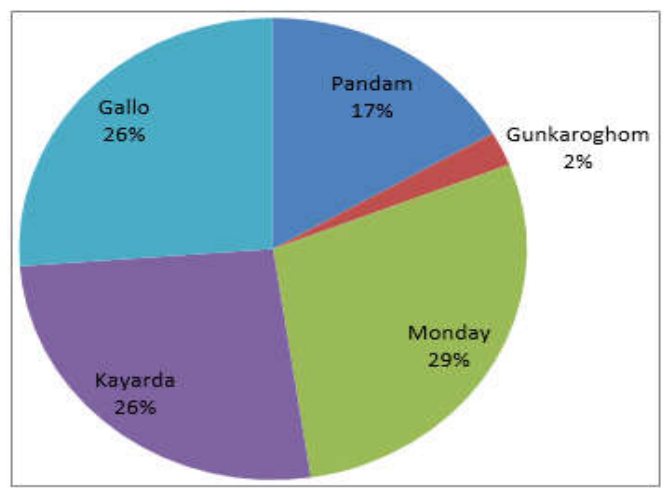

Fig 3: Proportion of meat protein sourced from bust meat in the study population from the five communities

Conclusion: It is concluded that socio-economic activities of people living around PGR mirrors to some extend anthropogenic activities going on in the Reserve. These socio-economic concerns must therefore, be addressed in practical terms for the 
achievement of biodiversity sustainability. This can be through strategic and sustained conservation education, engagement of community leaders in some decision making processes and provision of buffer zones. It is also recommended that PGR management should strengthen patrols around areas observed with trespasses in the reserve.

Acknowledgements: The authors are grateful to the Rufford Foundation UK for funding the project through nature conservation grant number 18060-1 awarded to Da'an, S. A. The valuable inputs of Dr. Ulf Ottoson and Dr. Yakhat Barshep during the project are also acknowledged.

\section{REFERENCES}

Abdu-Raheem, K A; Worth, S H (2013). Food security and biodiversity conservation in the context of sustainable agriculture: the role of agricultural extension. S. Afr. Tydskr. Landbouvoorl. S. Afr. J. Agric. Ext., 41: $1-15$

Akosim, C; Kwaga, BT; Ali, C; Mamman, GS (2007). Flora Resources and structure in Pandam wildlife Park Plateau state Nigeria. Agricultural Journal2 (6): $740-747$.

Anne,CC; Kai, MAC; Satterfield, T (2010).The role of people in conservation. In Sodhi and Ehrlich: Conservation Biology for All. Oxford University Press. Pp 262-283

Bibby,JC; Neil, DB; David, AH; Simon, M (2000): Bird census techniques (Second edition). Academic press.Pp 65-227

Carlos, A; Peter, RW; Frank, DZ (1998).Towards best practices forpopulationenvironmentpartnerships.Parks8 (1): 26-37

Chami, AA (2016). Roles of Socio-economic incentives towards sustainable Environmental Conservation of Kondoa Rehabilitated Rural Areas, Dodoma, Tanzania. DOI:10.4172/21577625.1000210

Conell, JH; Slatyer, RO (1977). Mechanisms of succession in natural communities and their role in community stability and organization. American Naturalist 111: 1119-44.

DeGeorges, PA; Reilly, BK (2009). The Realities of Community Based Natural Resource Management and Biodiversity Conservation in Sub-Saharan Africa. Sustainability 1:734-788
Dami, FD; Manu, SA (2008). The bird species at Pandam wildlife Park and the surrounding farmlands. Sci. World J. 3 (1): 7-11.

Evans, DM;Redpath, SM; Evans, SA; Elston, DA; Gardner, CJ; Dennis, P; Pakeman, RJ ( 2006). Low intensity, mixed livestock grazing improves the breeding abundance of a common insectivorous passerine. Biol. Lett. 2, 636-638

Emma-Okafor, LC; Ibeawuchi, II; Obiefuna, JC (2009). Biodiversity Conservation for Sustainable Agriculture in Tropical Rainforest of Nigeria. New York Science Journal. 2(7): 81-88.

Ezealor, AU, ed. (2002). Critical sites for biodiversity conservation in Nigeria. Nigerian Conservation Foundation: Lagos, Nigeria.

Fernández-Baca, JC; Martin, AS (2007). Indigenous Peoples and Protected Areas Management. Innovation in Conservation series Parks in Peril Program, The Nature Conservancy, Arlington, Virginia, USA.

Githiru, M (2007). Conservation in Africa: but for whom? Oryx 41(2): 119-120

International Council for Protection of Birds (1992). Putting biodiversity on the map: priority areas for global conservation. Published by The International Council for Bird Preservation (ICBP, now Birdlife International). The Burlington press, Cambridge UK 90

Joppa, L (2012). Population change in and around Protected Areas. J. Ecol. Anthropic. 15(1): 20112012

Kothari, A (2008). Protected areas and people: the future of the past. PARKS17 (2):23-33.

Mathisen, KM; Pederson, S; Nilsen, EB; Skarpe, C (2012). Contrasting responses of two passerine bird species to moose browing.Eur $J$ Wildl Res.53:535-547.

Mwansat, GS, Da'an SA, Nwabueze, E (2016). Seasonal responses of two faunal taxa to fire treatments in Yankari Game Reserve. FULafia Journal of Science \& Technology Vol. 2 (2): 8085.http://www.fulafiajst.com/publications/?rep onse $=2016$ 
Mbugua, $\mathrm{P}(2012)$. The Kenya Wildlife Service in the 21st Century. The George Wright Forum, 29 (1): 59-66.

Mohammed, I; Shehu, AI; Adamu, MB; Saleh, UF (2010). Comparative analysis of Fauna numerical characteristics of Yankari Game Reserve from 1980-2008. Environ. Res. Journal 4 (2):177-181

Mwanfupe, D (1998). Demographic impacts onprotected areas in Tanzaniaand options for action. Parks 8 (1): 3-14

Pickett, STA; Parker, VT; Fiedler, PL (1992). The new paradigm in ecology: implications for conservation biology above the species level. In: Fiedler, P.L. and Jain, S.K. (eds) Conservation Biology: the Theory and Practice of Nature Conservation, Preservation and Management. New York: Chapman and Hall.
Robert, J. S; Brian F. Powell (2006). Assessing the Effects of Human Activities on Wildlife.Visitor Impact Monitoring 23(2):50-58

Shanthikumar, SR; Atilola, MA (1990). Outbreak of Rinderpest in wild and domestic animals in Nigeria.Vet. Rec. 31; 126 (13):306-7.

Sherbinin, A; Freudenberger, M (1998). Migration to protected areas and buffer zones: can we stem the tide? Parks 8 (1):38-53.

Vickery, JA;Tallowin, JR; Feber, RE; Asteraki, EJ; Atkinson, PW; Fuller, RJ; Brown, VR (2001). The management of lowland neutral grasslands in Britain: effects of Agricultural practices on birds and their food resource. J. Appl. Ecol. 38:647-664 